\title{
Journey to the Land of the Dead: Traditional Chinese Beliefs in Trials before the Last Judgment
}

\author{
Alexander G. Storozhuk* \\ Saint-Petersburg State University \\ 7/9 Universitetskaia nab., St. Petersburg, \\ 199034, Russia
}

Received 30.11.2016, received in revised form 15.12.2016, accepted 12.01.2017

The article covers the traditional Chinese issue of the so-called "post-mortal journey" of a soul (or aggregate of souls) to the place of the Final Judgment, carried out by the Infernal Supreme Jury. The main goal of the research was an attempt to recreate a clear and consistent outline of this journey, having been fixed in the number of texts and traditional ritual forms throughout the centuries. The research is based on the comparative-historical method, founded on texts of the Chinese folksy religion and on the modern temple practices. As a result the produced outline gives the detailed characteristics of a great many minor gods and deities, believed to register, examine and convoy the newly deceased souls to the Inferno. The results of the survey may be useful for studies in the traditional Chinese religion, literature, art as well as for the comparative philosophic researches. Main conclusions of the research are:

"Minor gods of death" - a soul's first post-mortal guides and guardians-play a greater role in folksy beliefs than the headmasters of prominent departments of the Inferno.

These spirits become independent and unique phenomena no matter what classical religious traditions they ascend to.

In spite of being fearsome cruel these spirits happen to be somehow surprisingly attractive and dear to a common believer (which can be proved with the evidences from both: traditional Chinese customs and modern mass-culture).

Keywords: China, folksy beliefs, gods and deities, traditional culture, post-mortal judgement, history, religion.

DOI: 10.17516/1997-1370-0013.

Research area: philology.

\section{Introduction}

Death in a great many cultures is closely associated with the concept of a post-mortal journey that a soul undertakes from the place of death to the Land of the Dead. The Chinese idea of this journey is connected with special spirits that withdraw souls from a dead body, place them before authorities of the preliminary justice of the beyond, escort them during the last farewell visit to home and guide them to the

(C) Siberian Federal University. All rights reserved

* Corresponding author E-mail address: a.storozhuk@spbu.ru 
entrance to Inferno - precisely to the county of Fengdu in Sichuan province. These spirits are numerous and divisively described in different local traditions. Some of them ascend to Buddhist concepts, such as Hei Bai Wuchang (黑白無 常), some can be associated with Taoism (for example, Qianliyan and Shunfenger, 千里眼 順風耳), but the bulk belong in a sophisticated and poorly explored religious system, frequently called "Folksy beliefs". Hence those beliefs are vested with a certain system, and the picture of post-mortal wanderings of souls before entering Fengdu can be described in details with a proviso that local traditions are endless and can produce numerous deviations from the general pattern. The main sources of the system's re-creation will be religious and secular literary texts, starting from compendia of the 4-th century, such as Gan Bao (1957), and concluding with the classical Qin collections as "Zi bu yu" (Yuan Mei, 1993). The materials of the contemporary field studies (Storozhuk, Kornil'eva, Zavidovskaia, 2012; Storozhuk, 2011) have also been used in the described process.

\section{Post-mortal journey}

The post-mortal journey starts with the act of separation of the soul from a physical body. To be precise, here we speak not merely of a soul but of a complex combination of spiritual essences, of "souls" that number 10 in Chinese traditional beliefs. The attribution of those souls is a matter of a special research and somehow the attempts to characterize them have been undertaken (speaking of the last works - see Storozhuk, Kornil'eva, Zavidovskaia, 2012; Storozhuk, 2011, for example). In the light of the investigated topic the main thing to mention is a chief distinction between “yang” (陽) and “yin” (陰) souls that leads to diversification of special deities in charge of each of the groups. Thus, "extractors" of the souls are generally represented by unbreakable pairs of special spirits, the most important and celebrated of which are Hei Bai Wuchang (黑白 無常).

The very name of the spirits ascend to the Buddhist concept of inconstancy, unstableness of the nature-Anitya.Inconstancy means transience, and in the terms of the humble human existence the death. Thus, the embodiment of unstableness has become the spirit of death, and, as it has been stated above, not "a sprit" but "the spirits" since Wuchang normally come as pair deities. The White Wuchang (in the southern beliefs known as General Xie, 謝將軍) is uncommonly tall; his field of activities is withdrawal of "yang" souls hun (魂). The Black Wuchang (in the southern beliefs known as General Fan, 範將軍) is more often described as a short and ugly spirit, whose duties are to withdraw the "yin” souls - po (魄). These spirits are antagonistic and hence mutually complementary - the same way as yin and yang are. The beliefs in Wuchang were formed approximately during the reign of Ming (明, 1368-1644) and since then this special duo has been the main representation of the very idea of the death in the folksy beliefs. Simultaneously each of Wuchang spirits has some peculiar features of his own cult: for instance, White Wuchang is also commonly acknowledged as one of the Gods of Wealth, he has a large family and can become a relative of the living, but the examined topic lies a bit aside from all these particularities, and at this phase of investigation the only significant activities of Wuchang are their roles of soulextractors and convoy to the Land of the Dead.

To be precise, the same authority of soulextractors and guardians can be vested in another pair of spirits - in Qianliyan and Shunfenger (千 里眼順風耳), originally the guards of the Taoist sea goddess Mazu (媽祖). Qianliyan has the sharpest eyesight and Shunfenger - the keenest ear and are worshiped as endowers of these qualities, but while playing the role of the gods of 
death both of them get a new interpretation. Thus, the horn on the head of Shunfenger and two horns on the head of Qianliyan become the indicators of yin or yang essence of each of the spirits and, therefore, the duty of the extractor of yin or yang soles respectively.

The same modification of responsibilities can be observed in a great number of other examples of Buddhist or Taoist divinities having been transformed into the folksy gods of death, though the bulk of them are dealing with the authorities of final post-mortal justice and services of Hell. Here, in the first phase of a soul's afterlife wanderings the main roles are played by the folksy deities proper, and the central ones are Tudi (土地), the holy supervisor of a village (or a district), and Chenghuang (城隍), the heavenly protector of a city.

The first one dressed in a costume of an ancient official meets the soul and directs it to the preliminary court investigation, accomplished by Chenghuang and his boards. Speaking of the "soul" here we mean the receptacle of human consciousness, no matter what precise number of spiritual structures are congregated to form it; thus, further on we are going to speak of a "soul" in singular undergoing these or those procedures (for more details about the concept of a "soul" in reincarnations see Storozhuk, 2006). Tudi makes special notes in the files, which, starting from that moment, go along with the soul up to the stage of the final sentence.

Chenghuang, usually dressed as a Ming official, collects all data about the deceased and carries out a preliminary verdict. All the inquiry work for Chenghuang is done by 24 boards of his administration and by special prosecutors Pangguan (判官). The latter are usually represented by two special executives - Civil and Military ones. Number of Pangguan at the Last Justice is described differently, but the heads of all of them are the Four Great Pangguan, supervisors and fulfillers of the highest moral imperatives in the court of Ten Yanlowang (Shidian Yanwang, 十殿閻王).

The whole procedure of collecting evidences, interviewing witnesses, verifying testimonies etc. as well as a tremendous paperwork are carried out under the supervision of the main Cheghuang's assistant, the head of his administration and the mediator between life and afterlife activities Master of the Board of Yin and Yang - Yinyang si gong (陰陽司公). This deity can be easily recognized on the bulk of images since one part of his skin is white (or red), indicating yang, and the other one is black (or blue), indicating yin. Along with supervision over the preliminary investigation, Yinyang si gong stamps the special sacrificial banknotes and commands them directly to the Bank of Inferno; otherwise the banknotes will be considered illegal and can be sneaked out by the lonesome spirits.

After the preliminary verdict is pronounced the soul has the right to make the final visit to the native home. Depending on quantity of sins the person has committed, this visit can be undertaken with or without special convoy. The just one visits his home alone, the sinner - in chains or in stocks, escorted by a special fearsome spirit Shengshen (青神) or Shashen (邹神). Originally these two essences (Shengshen and Shashen) ascend to different traditions and used to have different functions, but in time both of them have been contaminated into one concept, still having different ways of denomination.

Shashen or Shengshen usually has a human body and a bird's feet, but may be described in many other ways, though his relations with birds are often noted: thus he may have a very unusual shape of face, resembling a beak. In the early legends Shashen is described as an evil force, gushing from a coffin and having an appearance of a giant bird, crying "Sha!" (Kill!). In later beliefs Shashen escorts the sinners during their farewell 
visit and treats them in the most unpleasant way. Thus, he hangs the sinners upside-down on any hook or nail he may find (that's why all nails and hooks at the day of presumable Shashen's visit should be sealed up with red paper, so that the spirit doesn't see them) and then eats the offerings, left by the relatives for the deceased. He also beats and humiliates the sinners, making their last coming to native home the most painful and bitter.

After the final duty has been paid, the soul can start a long traveling to the Land of the Dead, the entrance to which, as it was mentioned above, in the late tradition is associated with the county of Fengdu. This journey also demands at least two components: a guide and a special road-pass. Both of them need an individual and detailed description.

The just ones may be escorted to Fengdu by friendly and amicable deities, such as the mentioned Tudi or even God of the Hearth Zaowang (䆮王). Their role here is quite simple and obvious: to show the way and keep the company. Quite different is the situation with the sinners: they are convoyed to Fengdu either by Wuchang (or Qianliyan and Shunfenger depending on peculiarities of the local tradition) or by some special fearful guards, the most famous and important of whom are Niutou and Mamian ( 牛頭馬面). These two demons originally known as assistants of the Headmaster of Inferno Yanluowang (閻羅王) - in time obtain different new and unexpected qualities and duties, including this role of soul escort. Presumably being later interpretations of two great Vidyaraja (Mingwang, 明王) - Yamantaka (Daweide, 大 威德) and Hayagriva (Matou Mingwang, 馬 頭明王) - Niutou and Mamian become a sort of non-commissioned officers of the Hell and sometimes - even on the way to Hell. The only quality inherited from their Vidyaraja activities is strength, which they can use in rightening things; and being personifications of this strength they are quite important as convoy guards.

Road-pass (luyin, 路引) is another significant matter for the journey to Fengdu. These documents are bought, according to some local traditions, far in advance and kept along with the coffin and shroud. Other traditions recommend obtaining this luyin pass right after a person's death and filling it in two copies: one goes with the body into the coffin, the other one is burned during a sacrificial offering ceremony. Whatever method is chosen, the interpretation of luyin's usage is pretty much the same: this pass is needed during a long journey to Sichuan, and there - at Fengdu - it is the only license, giving the way through the Demons' Gate (Gui Men, 鬼 門). The ones without luyin will be held up at the very entrance to the Land of the Dead without a slightest hope to enter and continue the way in the wheel of incarnations.

Of course like all the items of folksy beliefs, luyin has a plenty of variations and dozens of usages: there are passes with special inscriptions on behalf of Ten Yanluowang Judges (Shidian Yanwang, 十殿閻王), indicating that the holder of the pass shall not be submitted to tortures and punishments of the Inferno, but effectiveness of such evidences is quite doubtful. In some traditions the passes are being kept during the whole life as mighty amulets, and so on.

Here at the Demons' Gate the first stage of the soul's traveling completes and a new phase of the afterlife trials commences.

For the studied matter one of the most curious issues about this traveling to Fengdu can be formulated in this way: in spite of the main importance of the afterlife reality having been vested in the Chief Judges of the Land of the Dead, into the highest Hell officials and the like, the cult of deities of this post-mortal wanderings' first segment is highly important in folksy beliefs of the Chinese. 
Speaking of the Old China (especially Ming and Qing dynasties), popularity of cults of these soul-extractors couldn't be overestimated. No matter what particular spirits were consideredWuchang, Qianliyan and Shunfenger or some vaguely explained Gouhungui (鉤魂鬼) with a bird's feet - their cult has been really essential. For instance, Wuchang were worshiped as special spiritual protectors of unhealthy children. A particular ritual established the relations between the family of a sick child and Wuchang, and up to the age of 16 the youngster remained a spiritual nephew of the deity. Ashes of the incenses, burnt in front of Wuchang, have been acknowledged as mighty remedy from a lot of diseases. Trying to get rid of illnesses people would hold special processions, at which they used to appear in Wuchang costumes and masks. White and Black Wuchang have become an essential part of folksy festivals and performances, fiction and popular prints. Nowadays in China there are a lot of souvenirs with the image of Wuchang - from T-shirts and key rings to toys and table-sculptures. Wuchang have become prominent figures of mass-culture, appearing in films, computer games, comicstrips, etc.

Practically the same goes to Yinyang si gong, Pangguan, Niutou and Mamian and other spirits and deities of the first phase of a soul's afterlife adventures.

\section{Conclusion}

Thus, we can come to some certain conclusions:

1. "Minor gods of death" - a soul's first post-mortal guides and guards - play a greater role in folksy beliefs than the headmasters of prominent departments of the Inferno.

2. These spirits become independent and unique phenomena no matter what classical religious traditions they ascend to.

3. In spite of being fearsome cruel these spirits happen to be somehow surprisingly attractive and dear to a common believer (which can be proved with the evidences from both: traditional Chinese customs and modern massculture).

\section{References}

Baranov, I. G. (1999). Verovaniia i obychai kitaitsev [Beliefs and Customs of the Chinese]. Moscow, Muravey-Guide, 303 p.

Charles, D. (1994). Orzech Mechanisms of Violent Retribution in Chinese Hell Narratives, In Journal of Violence, Mimesis, and Culture, 1, 111-126.

Clarke, G.W. (1898). The Yu-li or Precious Records, 28, Shanghai.

Erkes, E. (1940). The God of Death in Ancient China, In Toung Pao, 35, 1-3.

Gan Bao (1957). Sou shen ji [In Search of the Supernatural]. Shanghai, Shangwu yinshuguan, $156 \mathrm{p}$.

Glahn, Richard Von. The Sinister Way: the Divine and the Demonic in Chinese Religious Culture. Berkley, 2004, 385 p.

Groot, J. J. M. de (1907). The Religious System of China. Volume V Book II. Part II, Demonology, Part III, Sorcery. Leide, E. J. Brill, 454 p.

Kornil'eva, T. I. (2010). Traditsionniye kitaiskie predstavleniia o zagrobnom mire, otrazhennye v svode "Yuli Baochao": ortodoksalnyi biddism i narodnye verovaniia [Traditional Chinese Beliefs in Afterworld Reflected in "Yuli baochao": Orthodox Buddhism and Folksy Beliefs], In Vestnik SPBgU [Vestnil of St. Petersburg State University], Asian and African Studies, 13 (1), 91-105. 
Ma Shutian (1997). Zhongguo minjian zhushen [Complete Compendium of Deities of the Chinese Folksy Religion]. Beijing, Tuanjie chubanshe, 422 p.

Ma Shutian (1998). Zhongguo minjie zhushen [Complete Compendium of the Chinese Post-mortal Gods]. Beijing, Tuanjie chubanshe. 302 p.

Popov, P. S. (1907). Kitaiskii panteon [Chinese Pantheon], In Sbornik muzeya po antropologiyi I etnografiyi [Museum Almanac on Anthropology and Ethnography], 6, St. Petersburg, 207.

Rensheng baojian yuli baochao [Precious Miracle of a Human Life - Treasured Copies of the Jade Tablets]. Xylograph.

Storozhuk, A. G. (2006). Daosskaia teoriia dush i ee otrazhenie v tanskoi novelle [Taoist Theory of Souls and its Image in Tang Short Stories], In Vestnik NGU [Vestnik Novosibirsk State University], History and Philology, 5(4), Novosibirsk, 112-119.

Storozhuk, A. G. (2011). Concept of Soul in Chinese Folksy Beliefs, In The Silk Road: Papers from the International Conference, organized by Confucius Institute in Sofia, Bulgaria, June 3-4, 159-161.

Storozhuk, A. G. (2012). Demony sha (繁) v kitaiskoi novellistike [Demons Sha in Chinese Short Stories], In Problemy literatur Dalnego Vostoka. Materialy V mezhdunarodnoy nauchnoy konferentsii 27 iyunia - 1 iyulia 2012 goda [Issues of the Literatures of the Far East. Proceedings of the 5-th Learners' Conference, June 27 - July 1 2012], 1, St. Petersburg, 403-414.

Storozhuk, A. G., Kornil'eva, T. I., Zavidovskaia, Y. A. (2012). Dukhi I bozhestva kitaiskoi preispodnei [Gods and Spirits of the Chinese Inferno]. St. Petersburg, KARO, $464 \mathrm{p}$.

Taiping guangji (1959). [Extensive Records of the Taiping Era], 1-5, Beijing. 4106 p.

Xu Che (2006). Qu tan zhongguo shenxian [Discourse of the Chinese Spirits]. Tianjing. Baihua Wenyi chubanshe, $265 \mathrm{p}$.

Yü Ying-shih (1987). O Soul, Come Back: A Study in the Changing Conceptions of the Soul and Afterlife in Pre-Buddhist China, In Harvard Journal of Asiatic Studies, 47(2), 363-395.

Yuan Mei (1993). Zi bu yu [What the Master Would Not Discuss]. Xu zi bu yu [Continuation of What the Master Would Not Discuss], In Yuan Mei Quan Ji [The Complete Works by Yuan Mei],4, Nanjing, Jiangsu guji chubanshe, 728 p.

\title{
Путешествие в страну мертвых:
}

традиционные китайские представления

о мытарствах перед загробным судом

\author{
А.Г. Сторожук \\ Санкт-Петербургский государственный \\ университет \\ Россия, 199034, Санкт-Петербург, \\ Университетская набережная, 7/9
}

Статья посвящена традиционной китайской концепџии так называемого посмертного путешествия души (или совокупности душ) кместу последнего суда, проводимого выстими загробными инстанияями. Важнейшей иелью исследования была попытка воссоздать четкое и по- 
следовательное описание этого путешествия, зафиксированного на протяжении веков в ряде текстов и традицонных ритуальных практик. Исследование базируется на сравнительноисторическом методе, опирающемся на тексты простонародной китайской религии и на современные храмовые практики. В результате полученное описание представляет детальные характеристики множества второстепенных божеств и духов, которые, по поверьям, осуществляют учет, проверку и сопровождение душ новопреставленных в китайскую преисподнюю. Результат исследования может быть полезен всем, кто изучает традиционную китайскую религию, литературу, искусство, а также важен для сравнительно-философских исследований. Главными выводами статьи являются следующие:

«Второстепенные божества смерти» - первые сопроводители и охранники новопреставленной души - играют более важную роль в простонародных верованиях, чем руководители крупных департаментов преисподней.

Эти духи играют самостоятельную и уникальную роль в традииионной культуре вне зависимости от того, к какой классической религиозной традиции они восходят.

Несмотря на свирепость, эти духи воспринимаются верующими с удивительным расположением и симпатией (что подтверждается свидетельствами как из традиционных китайских реалий, так и из современной массовой культуры).

Ключевые слова: Китай, простонародные верования, духи и божества, традиционная культура, загробный суд, история, религия.

Научная специальность: 10.00.00 - филологические науки. 